\title{
MAJESTY
}

MASPUL JOURNAL OF ENGLISH STUDIES

| ISSN 2657-0157)(Online) |

\section{Enhancing Student Reading Skill through Strategy of Directed Reading Thinking Activity (DRTA)}

\section{Umiyati Jabri'1, Nurmi Nadhira²}

${ }^{1}$ (English education Department, Universitas Muhammadiyah Enrekang, Indonesia), ${ }^{2}$ (Elementry School Education, Universitas Muhammadiyah Enrekang, Indonesia)

Email: umiyatijabri@gmail.com

\section{ARTICLE INFO}

Article History:

Received May 15, 2020

Revised July 13, 2020

Accepted July 15, 2020

Keywords:

Directed Reading

Thinking Activity,

Reading Ability

\begin{abstract}
This research examines the effect of the DRTA strategy as an effort in enhancing the students' reading comprehension skills in class V SD 41 Enrekang. A research methodology is a quantitative method for classroom action research. This review focuses on student learning outcomes and processes. The study was conducted at Enrekang 41 Elementary School, Enrekang, with the subject of the fifthgrade students of Enrekang 41 Elementary School, Enrekang, consists of 21 students. The CAR is carried out in four stages: planning, implementing actions, observing, and reflecting. From the implementation obtained data collected by learning outcomes tests. Then the data is analyzed and processed quantitatively. The results of the study showed that Directed Reading Thinking Activity (DRTA) in the first cycle is in the less category (K), and after the second cycle action is carried out, there is an improvement in students' scores and has reached the specified indicators. From the result, the researcher concludes that the students' reading comprehension skills in Indonesian subjects in class V SD 41 Enrekang, Enrekang Regency has an improvement after applying of the strategy of Directed Reading Thinking Activity (DRTA).
\end{abstract}




\section{Introduction}

Reading skill is highly important for everyone especially for students. That is because almost all daily activities always involve the reading skill, starting from reading traffic signs to reading books and newspapers for daily use. Because of the importance of reading skills in daily life, therefore it is very important to prepare students from an early age with reading skills because reading is the main asset in the learning process. According to Cunha (2006). The most important time in which parents engage in cognitive skills (reading skills) is early in the lives of their children (Ismail, I., Elihami, E., \& Mustakim, M., 2019).

Through reading learning, students are expected to provide appropriate responses to information that has been read (Musdalifah, 2020). In addition, reading can also be the key to gain knowledge (Ismail, 2019). And with these keys students will be able to explore various sciences and take benefits of what they have read to optimize the learning goals. Moreover, reading will inspire them to read their own books and improve their cognitive know-how (Canoy et al., 2006).

Reading comprehension is one of the subjects that must be mastered in Indonesian subjects from grade IV to grade VI Elementary School. For this reason, this research was chosen as an effort to enhance the students' low reading comprehension ability in grade $\mathrm{V}$ elementary school, and also as a reference for educators, especially teachers to adjust the reading material given to students.
The low student learning outcomes are caused by two factors namely, teacher factors and student factors. From the teacher factor that is, learning is still carried out in a conventional way where students are given reading assignments at school or home. The task was to answer questions about the contents of the reading (Hasan, H., \& Ismail, I., 2020). The process of students reading is not the main goal (Elihami, E., \& Ismail, I., 2017). The goal is students work on assignments and exercises according to the teacher's wishes.

The results of pra-observations at the school can be concluded S follow (1) learning to read using less innovative strategies; (2) students' reading activities are limited to assignments and exercises; (3) the lack of interest in reading students makes low levels of student understanding of the content of the reading only if students are allowed to reopen the reading; (4) the low capability of the students in using their own language (Ismail, 2019) to understand and convey the content of the reading material that they have read (5) the lack of functioning of the school library as a means of reading for students; (6) there is no literacy program at the school.

Because this condition of Enrekang 41 Public Elementary Schools needs to be immediately improved. One of the solutions to face this problem is an alternative reading learning application with different models, techniques, approaches, and strategies. Furthermore, the alternative applications that are chosen should cover the overall level of student understanding, both in the 
understanding and conveying the content of the reading material in orally and writing.

In order to decrease the negative effect on students' inability to understand and communicate the material content, we need a solution directed towards the phase of understanding. The Direct Reading Think Activity (DRTA) strategy is an alternative solution to the problem used to improve comprehension reading skills. For this reason, the researchers want to implement the DRTA strategy, in order to improve the students ' poor learning skills.

Stuffer describes in Mehdi the DRTA as follows: "Stauffer in 1969 created the Guided Reading Learning Practice (DRTA). The DRTA is a strategy that leads students to question $a$ predicted text and to read it to confirm or refute its predictions. Indeed, DRTA allows teachers to guide students through anticipation, projection, and subsequent confirmation and modification of their ideas by thinking as good readers do in history. DRTA is primarily used for fiction, but for nonfiction it can be used effectively as well.

The key point of the Direct Reading Thinking Activity (DRTA) strategy is the existence of an active process, the occurrence of problemsolving activities, and the reader uses prior knowledge to understand the reading. This strategy focuses on students' involvement with the text because students predict and prove it when reading. Initially, students are invited to make predictions about what is in the text through pictorial media that can encourage children to think about the message in the text. Then in making predictions, students use their initial knowledge about the topic and knowledge about the arrangement of the text. Each child's prediction will be different because students think according to the students' own mindset, and the teacher must accept all predictions put forward by students. Furthermore, after predicting the picture before the students are given reading material. This explanation is central to this DRTA Technique, which will promote students ' comprehension of the quality of reading through their use in learning.

The teacher introduces reading, by conveying some of the readings material, according to Abidin (2012) in the D RTD strategy as follows. (2) The students anticipate reading and read it. If students are not yet able to make predictions, the teacher will ask students. Efforts have been made to make a lot of predictions so that there will be groups that agree and groups that disagree. 3) Students read a speech in silence to check the predictions they made. At this point, teachers must consider the meaning of reading, be able to concentrate on student reading actions and make it difficult for students, by presenting word examples, to understand the meaning of words, without specifically referencing the meaning of the word. 4) Test predictions, students at this stage, are required to check the predictions that have been made. When students' forecasts are false, students must show where the discrepancy is and be able to give a new photograph of the actual speech content. 5) Training of basic skills. The students complete this stage 
to develop their thought skills. Some of the activities students perform are to retest the past, retell the plot, sketches, schemes or read concept cartes and create a traveling map of a character (a trip that displays a character 's presence at a variety of events).

Directed Reading Thinking Activity (DRTA) has numerous reasons which give many advantages in learning to read and teach. The key benefits of this DRTA will help create essential reading skills and strategies that enable students to become successful readers. The researchers thought that it was appropriate to conduct classroom action research entitled "Implementing the Strategy of Directed Thinking Activities (DRTA) for improving student reading ability in Class V in Class 41 Enrekang Regency" based on these descriptions.

\section{Methodology}

This work will follow the main research project of the four-stage Classroom Action Research (CAR), which involves the planning, execution, evaluation and reflection of action. According to Sagor, it is mainly because it helps "the actor" to enhance and/or refine his actions "(Sagor, 2000). This work will take place roughly two years. They are the first and second cycles, and each cycle has a close relationship to a series of activities. Where second cycle implementation was continued and the first cycle was repaired.

Data collection techniques used in this study is using the test. Researchers used to test techniques to measure students' reading skills. According to Kusumah and Dwitagamaa (2010: 7879), a test is a set of stimuli given to someone with the intention to obtain answers as a determination of score scores. Tests are carried out to determine student learning outcomes. Learning outcomes intended cognitive learning outcomes in the form of numbers. Tests in this study in the form of short answer questions about reading comprehension and description questions in summarizing the contents of the reading. Data collected in the form of learning outcomes using minimal completeness criteria (KKM) of Indonesian subjects. In this study, the test technique is used to measure improvement in reading skills as student learning outcomes through the Directed Reading Thinking Activity (DRTA) strategy. This test is implemented in the learning cycle I and cycle II.

\section{Result}

a. Cycle I

In the first-cycle learning process, which took place on Wednesday, 20 March 2019, researchers and the fifthgrade teacher were the observers. first Researchers and observers (Class V Teacher) plan and prepare the things that are necessary for the implementation of the action properly. In the implementation of these actions, the teacher has tried to implement the strategic steps of the Directed Reading Thinking Activity (DRTA) that have been planned. In this cycle I the result of the students' score only $42.85 \%$. It means the score is still not achieved the minimum standard score.

\section{b. Cycle II}

In the learning process in the second cycle which was carried out on 
Monday, April 1, 2019, the acting act was the researcher and the teacher acted as the observer. In the implementation of this action, researchers try to make improvements so that the deficiencies in the first cycle can be overcome in the second cycle. The implementation of the second cycle is still implemented by implementing the Directed Reading Thinking Activity (DRTA) strategy.

Based on the test results, an optimum performance of the action cycle II is shown. It can be seen from the observations of researchers and students and student learning outcomes are increasing. The percentage of classical completeness obtained was $90.47 \%$. The data is under the expected success indicators. It can be concluded that the Strategy of Directed Reading Thinking Activity (DRTA) could strengthen the reading capacity of students in class V of SD Negeri 41 Enrekang based on the results from research and data analyses.

\section{Discussion}

In cycle 1 The percentage of Students' scores is $42.85 \%$. This happens because there are still some deficiencies found in the implementation. The deficiencies found in the activities of the researcher and students carried out in the first cycle are: (1) researcher does not ask inducement questions to arouse student predictions, so it does not arouse student curiosity. (2) Researchers do not guide students to check the truth of their predictions and adjust their predictions, so students are confused about whether the predictions are correct or not. (3) the researcher did not direct the students to pay attention to the title and image again before making a prediction when repeating the procedure 1 to 4 steps of the Directed Reading Thinking Activity (DRTA) in the next continued text. While the weaknesses of the student factors are, 1) some students do not adjust their predictions, students do not judge the accuracy of their predictions, students cannot show the part of the text that supports their predictions and when repeating the steps Directed Reading Thinking Activity (DRTA) some students no longer predict the next section of text that has been divided.

In Cycle 2 As there are some differences that the researcher applies the strategy Directed Reading Thinking Activity (DRTA) based on deficiencies that occurred in cycle I. They are the researcher has written the title, the researcher has given an inducement question, the researcher has shared the reading text to all students, the researcher has guided all students to check the truth of their predictions, researchers have guided all students whose predictions are almost or not quite right to adjust them to the text, the researcher has repeated the procedure 1 to 4 steps Directed Reading Thinking Activity (DRTA) sequentially until all learning process has been covered, the researcher has instructed students to read silently.

While from the aspect of students, students have enthusiastically followed the learning by paying close attention to the titles displayed by researchers, students have responded to the questions of researchers and made predictions based on titles, all students have been disciplined in reading silently, students have dared to read 
Majesty Journal, 2 (2), 2020 - 23

Umiyati Jabri; Nurmi Nadhira their predictions, students have repeated steps 1 to 4 in the next text well.

\section{Conclusion}

The research results and the data analysis show the potential of the Strategy of Directed Reading Thinking Activity of students in class $\mathrm{V}$ of SD Negeri 41 Enrekang to improve their reading ability. The data showed when applying the Directed Reading Thinking Activity (DRTA) strategy in Indonesian subjects has significantly increased. students who completed as many as 8 people (38.9\%) and those who did not complete as many as 13 people $(61.90 \%)$ in cycle I, then in the second cycle a significant increase occurred in students as evidenced by learning outcomes using Directed Reading Thinking Activity (DRTA ) students who completed as many as $19(97.90 \%)$ and as many as $2(2.10 \%)$ students did not complete.

\section{References}

1) Abidin, Yunus. (2012). Pembelajaran membaca berbasis Pendidikan Karakter. Bandung: Pt. Refika Aditama.

2) Canoy, M., J.C. van Ours, and F. van der Ploeg (2006). The economics of books: Victor A. Ginsburgh and David Throsby (eds.), Handbook of the Economics of Art and Culture, Amsterdam, Elsevier, 721-761.

3) Cunha, F., J.J. Heckman, L.J. Lochner, and D.V. Masterov (2006). Interpreting the evidence on life cycle skill formation, in Hanushek, E.A. and F. Welch (eds.) Handbook of the Economics of
Education, Amsterdam, Elsevier, 697-812

4) Hasan, H., \& Ismail, I. (2020). The Effectiveness of Material Based Stories in Improving Students Reading Comprehension. MAJESTY JOURNAL, 2(1), 40-46. https://doi.org/10.33487/majest y.v2i1.332

5) Elihami, E., \& Ismail, I. (2017). Increasing Students' Reading Comprehension Through Cognitive Strategies of Senior High School of Sidenreng Rappang Regency. Edumaspul Jurnal Pendidikan, 1(2), 61-70. https://doi.org/10.33487/eduma spul.v1i2.41

6) Ismail, I., Elihami, E., \& Mustakim, M. (2019). Students' Perceptions of the Benefits of Mobile Polling Technology in Teaching and Learning in College: Implications of Students' Participation and Academic Performance. Jurnal Pendidikan Progresif, 9(1), 89104. Retrieved from http://jurnal.fkip.unila.ac.id/inde x.php/ipp/article/view/17871

7) Ismail, I. (2019). Converting a Story from Students' Own Language in English to Increase Speaking Ability. MAJESTY JOURNAL, 1(1), 5-18. https://doi.org/10.33487/majest y.v1i1.54

8) Ismail, I. (2019). The Impact of Interactive Reading Using Local Folktales Stories in Supporting Students' Vocabulary Achievement in Indonesian EFL Learners. MAJESTY JOURNAL, 1(2), 25-37. https://doi.org/10.33487/majest y.v1i2.119 
Majesty Journal, 2 (2), 2020 - 24

9) Masnur, M., \& Usman, M. (2019). Application of the Questions Students Have to Improve Activities and Results of Learning Students. MAJESTY JOURNAL, 1(2), 20-24. https://doi.org/10.33487/majest y.v1i2.118

10) Mohammad Mehdi Yazdani, “ Explicit Instruction of Reading Strategies:

DirectedReadingThinking Activity vs. Guided Reading Strategies". International Journal of Applied Linguistics \&English Literature. ELT Department, Faculty of Persian Literature and Foreign Languages, Roudehen Branch, Islamic Azad University, Roudehen, Iran. Vol. 4 No. 3 (May 2015), h. 2.
11) Musdalifah, M. (2019). The Comparison of Mind Mapping and Semantic Mapping to Enhance Reading Comprehension. MAJESTY JOURNAL, 1(2), 1-9. https://doi.org/10.33487/majesty .v1i2.117

12) Kusuma, Wijaya and Dwitagama, Dedi. (2010). Mengenal Penelitian Tindakan kelas. Jakarta; Pt Indeks

13) Sagor, R. (2000). Guiding School Improvement with Action Research. USA: Association for Supervision and Curriculum Development Retrieved from http://www.ascd.org/publication s/books/100047/chapters/WhatIs-Action-Research\%C2\%A2.aspx 